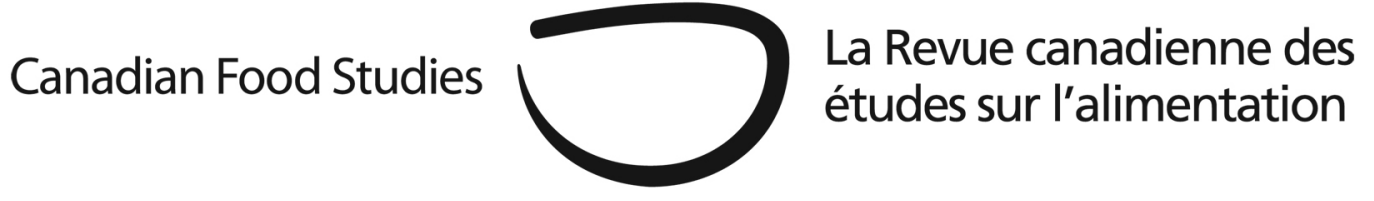

Book Review

\title{
Changing the food game: Market transformation strategies for sustainable agriculture
}

Lucas Simons

Greenleaf Publishing, 2014: 268 pages

Review by Adam Sneyd (University of Guelph)

Experts in the area of new agricultural standards, codes, and certifications tend to hold strong perspectives on the reforms that they believe will transform unsustainable conventional farming practices. However, these important practitioner points of view infrequently make a big splash in global conversations and debates on the future of agriculture. The perspectives of philanthropists, celebrities, and generalists have of late received more attention than those of insider-type individuals that address this issue from their own particular technical or analytical perspective. And it is this gap that certification, farmer organization, and agricultural development consultant Lucas Simons seeks to fill in his new and highly accessible book Changing the Food Game. Scholars should take note of this creative approach to rendering the transformation of agriculture more meaningful and exciting to a broader audience. Conference panels and journal articles on standards, codes, and certifications have absolutely pushed knowledge generation on this topic in new and needed directions. But these academic exercises are fundamentally exclusive, and can be devoid of substantive social impact.

Simons marches into this void trumpeting his own experience as a Director with UTZ Certified, a smaller global sustainability standard for coffee, tea, and cocoa. From the get-go, 
Simons' experience with this particular initiative informs his presentation of the history of market transformation through certification. In recounting "where it all began" in his first chapter, for example, Simons seemingly downplays the rise of parallel approaches before and concurrent to the emergence of UTZ, including organic standards and fair trade certifications. But the limits of his presentation on the specifics of this history do not ultimately undermine the effectiveness of his book. The "value added" to the literature from this instance of experienceinformed expert writing - so to speak - is that it offers an original market-oriented approach to conceptualizing change in complex agricultural systems.

Simons painstakingly and in simple language shows his readers how they can grasp these complex systems through thinking "in loops" about the forces and factors that reinforce unsustainable practices. To do so he offers an incredible array of useful figures and charts that offer food for thought to laypeople and practitioners alike. He then employs his systems thinking and rigorously documents what he terms the "phases" of market transformation that can be gleaned from his experience with internationally traded agricultural products. And to reinforce his perspective, he offers a must-see graphical appendix that imparts the evidence he has for considering market transformation in coffee, cocoa, and palm oil to have followed similar trajectories. To summarize briefly, Simons views change to stem from an initial "awarenessraising phase" where NGOs blow the whistle on bad practices, and projects are launched to ameliorate the underlying problems that have been called out. He then delineates a second "firstmover phase" where entrepreneurs seek to address the underlying problem more durably than the initial responses. Subsequently, Simons argues that a critical mass or "institutionalization phase" is reached when the new sustainability standards set by the first-movers become more broadly established. He terms the fourth and final phase "leveling the playing field", and argues that in this period civil society groups, standards bodies, corporations, and governments are called upon to work together to implement and align sustainability practices that have entered the mainstream.

While much of Simons' work on this front is convincing and I highly recommend this book, from a political economy perspective, I do have some concerns. Simons underscores the importance of politics during his "awareness-raising" phase, but does not do enough to bring out the politics and political implications associated with the subsequent phases he identifies. As such, in my view, he overplays the market-driven nature of agricultural transformation. Simons also offers his readers a limited lens through which to view the power that standards, codes, and certifications can wield relative to each other, and also to the markets they set out to govern. In cotton, for example, it is clear that different approaches to agricultural transformation can yield very different sustainability results. Lowest common denominator-type approaches tend to command more power than others that have a demonstrated potential to foster meaningful change. Despite this significant limitation, the value added remains. But so too does the question of impact. In seeking to speak to a mass audience, Simons should enable more people to comprehend the importance of standards, codes, and certifications than otherwise would take an interest. Whether this type of intervention will move these issues higher up the global agenda for 
food and agriculture policy and decision-makers nonetheless remains to be seen. I for one hope that his effort represents the first of many "insider" accounts that help people to better understand what is being done to their food by the experts seeking to make agriculture more sustainable.

Adam Sneyd is an associate professor in the Department of Political Science and the International Development Studies Program at the University of Guelph. He conducts research on the political economy of commodities and development. 